\title{
APPLICATION OF STANDARD GERMINATION AND VIGOUR TESTS FOR SEED QUALITY ASSESSMENT OF MAIZE INBRED LINES
}

\author{
Marija Milivojević ${ }^{1}{ }^{\star}$, Jelena Srdić ${ }^{1}$, Milomir Filipović ${ }^{1}$, Tanja Petrović ${ }^{1}$, Dragana \\ Branković Radojčić1, Ksenija Marković1 , Jan Boćanski
}

\begin{abstract}
Information regarding the adaptation of maize (Zea mays L.) inbred lines to various field conditions and seed longevity is essential for seed companies. The objective of this work was to evaluate different vigour tests for detecting differences among naturally aged seeds and to assess the relationship between seed quality parameters and pedigree data of maize inbred lines. A seed of 15 maize inbred lines, selected at Maize Research Institute Zemun Polje, belonging to different heterotic groups was produced during 2011. Seed quality was assessed in 2015 by standard germination, radical emergence, accelerated ageing, and cold test. Root length of 4-day old seedlings was measured in all applied tests. Analysis of variance showed that genotype and storage conditions had a significant effect on all seed quality parameters. Large variation among inbred lines was detected in seed vigour determined by three tests, in particular by the accelerated ageing test. Cold test results showed very good chilling tolerance of tested genotypes, except two inbred lines with Lancaster background. The correlation between the cold test and the accelerated ageing test was significant, while the radical emergence test had a poor correlation with them. Obtained results indicate that the application of either cold test or accelerated ageing test is reliable for screening seed vigour of maize inbred lines.
\end{abstract}

Key words: inbred lines, germination, maize, seed quality, vigour

\section{Introduction}

Profitable maize seed production relies on the seed quality of inbred lines. Seed quality is one of the main factors affecting the early performance and productivity of this important agricultural crop (Sabry, 2018). It is influenced by inbred line genetics, the chemical composition of seed, and environmental conditions during seed production. Selecting inbreds for high seed quality early in the breeding program is beneficial and important for improving germination and field performance (Goggi et al., 2007). Among other selection criteria, tolerance to low temperatures during early emergence is gaining increasing attention among maize breeders (Darkó et al., 2011; Frascaroli and Landi, 2013; Strigens et al., 2012, 2013; Grzybowski et al., 2019). Breeding maize for early sowing requires base germplasm with the ability to germinate and grow vigorously under cold conditions. Several authors have identified maize genotypes appropriate for cultivation under cold conditions or early field sowings (Revilla et al., 2014; Li et al., 2021).

\footnotetext{
Original Scientific Paper (Originalni naučni rad)

Milivojević M, Srdić J, Filipović M, Petrović T, Branković Radojčić D, Marković K, Maize Research Institute Zemun Polje, Slobodana Bajića 1, 11185, Belgrade, Serbia

${ }^{2}$ Boćanski J, Faculty of Agriculture, University of Novi Sad, Trg Dositeja Obradovića 8, 21000 Novi Sad, Serbia

*e-mail: mmarija@mrizp.rs
} 
Early sowing of maize enables a longer growing season with a better possibility of achieving higher and more stable yields and better chances of avoiding summer droughts (Bonelli et al., 2016; Tsimba et al., 2013). That is especially important to the regions with cold and wet springs and extremely dry and hot summers.

To estimate seed performances in sub-optimal field conditions numerous vigour tests have been developed. There are results that accelerated ageing test (AA) and cold test (CT) are the most appropriate vigour tests for predicting maize performance in the field (Woltz and TeKrony, 2001). The accelerated ageing test was originally developed to evaluate the storage potential of seed lots (Delouche and Baskin, 1973) but also utilized to measure seed vigour in many species including maize (Andrade et al., 2020; Nerling et al., 2018). Although widely used, the disadvantages of AA and CT are the duration of evaluation and lack of standardization for testing maize seed vigour.

Some researches indicate that the rate of physiological germination (production of 2 $\mathrm{mm}$ radicle) is related to the field emergence of commercial maize seed lots (Khajeh-Hosseini et al., 2009 Matthews et al., 2010; 2011). They have found that mean emergence time and radicle emergence test (both at $20^{\circ} \mathrm{C}$ and 13 ${ }^{\circ} \mathrm{C}$ ) was effective in screening maize seed lots by vigour and achieved comparable results to cold test and field emergence.

Initial seedling growth is directly correlated to maize seed vigour (Mondo et al., 2013). Seedling size and uniformity are important indicators of seed quality, nevertheless measuring procedure is time- consuming and inadequate for daily usage in laboratory testing. To reduce testing time and to remove subjectivity from vigour testing, seed imaging has been used effectively in species of large crops, such as maize (Alvarenga et al., 2012; Medeiros et al., 2019). Root length and coleoptile length in standard germination tests have been proved to be valid indicators of maize seed vigour (Pinto et al., 2015). A positive correlation with other vigour tests such as AA, CT, first count in standard germination, seedling emergence at $25^{\circ} \mathrm{C}$ and seedling emergence index at 25 and $30{ }^{\circ} \mathrm{C}$, has been established.

The objective of this work was to compare vigour tests in identifying differences between maize seeds naturally aged in different conditions and identifying the most suitable test for seed quality evaluation of maize inbred lines in the laboratory. Also, the aim was to assess the relationship between seed quality traits and the known pedigree of maize inbred lines.

\section{Materials and Methods \\ Plant material}

This research included 15 maize inbred lines selected at Maize Research Institute Zemun Polje, which are adapted to the mid-continental climate of Serbia. Those inbreds, belonging to various maturity and heterotic groups, are components of commercial ZP hybrids (Table 1). The seed was produced by self-pollination in 2011 at the location of Zemun Polje. The seed was hand-husked, sieved through a $5 \mathrm{~mm}$ sieve, and dried until optimal seed moisture was reached (between 11 and 13\%).

Laboratory tests were conducted during 2015. Seed produced in 2011 was stored in controlled conditions at $18{ }^{\circ} \mathrm{C}$ and $60 \% \mathrm{RH}$ (storage room conditions), and in a cold chamber at $5{ }^{\circ} \mathrm{C}$ and $60 \% \mathrm{RH}$. The untreated seed was used for all the tests. 
Table 1. The list of maize inbred lines and their pedigree

Tabela 1. Lista samooplodnih linija i njihov pedigre

\begin{tabular}{rcl}
\hline No & Inbred line & \multicolumn{1}{c}{ Pedigree } \\
\hline 1 & ZPL1 & Iowa Dent \\
2 & ZPL2 & Iowa Dent \\
3 & ZPL3 & Lancaster \\
4 & ZPL4 & Iowa Dent $x$ unrelated germplasm \\
5 & ZPL5 & Lancaster \\
6 & ZPL6 & Lancaster \\
7 & ZPL7 & Lancaster \\
8 & ZPL8 & BSSS x Iowa Dent \\
9 & ZPL9 & BSSS x unrelated germplasm \\
10 & ZPL10 & BSSS x exotic germplasm \\
11 & ZPL11 & BSSS x Iowa Dent \\
12 & ZPL12 & BSSS \\
13 & ZPL13 & BSSS \\
14 & ZPL14 & BSSS \\
15 & ZPL15 & BSSS \\
\hline
\end{tabular}

\section{Laboratory tests}

Standard germination (SG). The standard germination test was conducted according to the ISTA Rules (2015). Between paper method was applied, $20 / 30{ }^{\circ} \mathrm{C}$ temperature, with day/night period lasting $8 \mathrm{~h} / 16 \mathrm{~h}$. Evaluation of normal seedlings was done after 4 days (First count - FCSG) and after 7 days of germination.

Cold test (CT). The cold test described in Handbook for Vigour Testing (Hampton and TeKrony, 1995) was modiffied by applying more stresful conditions. Seeds were exposed to cold temperatures $\left(7.5^{\circ} \mathrm{C}\right)$ for 10 days in rolled paper towels with moist sand and then exposed to conditions described for SG.

Accelerated ageing (AA). The procedure for the accelerated ageing test in Handbook for Vigour Testing (Hampton and TeKrony, 1995) was followed. Seeds were exposed to high temperatures $\left(43{ }^{\circ} \mathrm{C}\right)$ in combination with high relative humidity $(95 \% \mathrm{RH})$ for $72 \mathrm{~h}$. Inner AA boxes Hoffman Manufacturing Inc., OR, USA $(11 \times 11 \times 3.5 \mathrm{~cm})$ were used. Seeds (about $40 \mathrm{~g}$ ) were placed in one layer on a wire mesh screen. Mashes were placed into AA boxes with $40 \mathrm{ml}$ of distilled water at the bottom. After treatment with high temperature and $\mathrm{RH}$, seeds were placed for standard germination within one hour. Immediately after the ageing period, seed moisture was determined by the enlargement of seed weight, which turned out to be within the recommended range (26-29\%) in all cases.

Root length (RL). As an additional parameter of seed vigour, root length was measured after four days of germination in the standard germination test. In CT and AA tests, stressful period was not taken into account, so root length was measured 4 days after germination in optimal conditions.

Radicle emergence test (RE). Evaluation of radicle emergence was carried out according to ISTA Rules (2015). The temperature of $20{ }^{\circ} \mathrm{C}$ was applied, the duration of test was $66 \mathrm{~h} \pm 15$ minutes, and the criterion for evaluation was the presence of $2 \mathrm{~mm}$ or longer radicle.

\section{Statistical analysis}

Analysis of variance (ANOVA) was performed after angular transformation arcsin sqrt (\%) of the data expressed as percentages (SG, FC, CT, AA, and RE). LSD test was applied for testing significant differences between mean values. MSTAT computer program was used for that statistical analysis. Spearman co- 
efficient of correlation was calculated between all applied tests (standard germination and vigour methods).

\section{Results}

Genotype and storage conditions had a significant influence on all investigated seed quality parameters as shown by analysis of var- iance (Table 2). This was also confirmed by the LSD test which revealed significant differences between genotypes concerning all seed quality parameters (Table 4). The interaction between genotype and storage conditions had also a significant influence on examined traits, except in the case of root length in the cold test (Table 2).

Table 2. Analysis of variance of investigated maize seed quality traits

Tabela 2. Analiza varijanse ispitivanih parametara kvaliteta semena kukuruza

\begin{tabular}{cccccccccc}
\hline \multirow{2}{*}{$\begin{array}{c}\text { Source of } \\
\text { variation }\end{array}$} & \multirow{2}{*}{ Df } & \multicolumn{7}{c}{ Mean squares } \\
\cline { 2 - 9 } & & RE & FCSG & SG & CT & AA & RLSG & RLCT & RLAA \\
\hline Replicates & 1 & $35.50^{\text {ns }}$ & $72.62^{\text {ns }}$ & $13.18^{\text {ns }}$ & $0.01^{\text {ns }}$ & $5.81^{\text {ns }}$ & $0.58^{*}$ & $1.26^{\text {ns }}$ & $0.29^{\text {ns }}$ \\
G & 14 & $440.62^{* *}$ & $149.24^{* *}$ & $90.83^{* *}$ & $353.38^{* *}$ & $1101.96^{* *}$ & $1.51^{* *}$ & $5.21^{* *}$ & $9.12^{* *}$ \\
SC & 1 & $4070.07^{* *}$ & $1035.09^{* *}$ & $950.74^{* *}$ & $657.76^{* *}$ & $6078.46^{* *}$ & $5.34^{* *}$ & $7.56^{*}$ & $132.02^{* *}$ \\
G x SC & 14 & $208.20^{* *}$ & $244.13^{* *}$ & $169.05^{* *}$ & $396.91^{* *}$ & $179.25^{* *}$ & $1.07^{* *}$ & $1.08^{\text {ns }}$ & $2.09^{* *}$ \\
Error & 29 & 21.86 & 41.15 & 31.42 & 38.73 & 31.67 & 0.08 & 1.08 & 0.47 \\
CV & & $15.00 \%$ & $8.76 \%$ & $7.13 \%$ & $8.71 \%$ & $8.97 \%$ & $5.26 \%$ & $10.80 \%$ & $15.40 \%$ \\
\hline
\end{tabular}

G - genotype; SC - storage conditions; RE - radicle emergence test; FC - first count in standard germination test; SG - standard germination, CT - cold test, AA - accelerated ageing test, RLSG - root length in SG, RLCT - root length in CT, RLAA - root length in AA

Table 3. Effect of maize seed natural aging on laboratory test results; average values and significant differences Tabela 3. Uticaj prirodnog starenje semena kukuruza na rezultate laboratorijskih testova, prosečne vrednosti $i$ značajnost razlika

\begin{tabular}{lcccccccc}
\hline & RE & FCSG & $\begin{array}{c}\text { SG } \\
(\%)\end{array}$ & CT & AA & RLSG & $\begin{array}{c}\text { RLCT } \\
(\mathbf{c m})\end{array}$ & RLAA \\
\hline Storage room & $17.9^{\mathrm{b}}$ & $84.5^{\mathrm{b}}$ & $90.8^{\mathrm{b}}$ & $82.1^{\mathrm{b}}$ & $63.1^{\mathrm{b}}$ & $4.95^{\mathrm{b}}$ & $9.18^{\mathrm{b}}$ & $2.97^{\mathrm{b}}$ \\
Cold chamber & $40.8^{\mathrm{a}}$ & $93.2^{\mathrm{a}}$ & $96.5^{\mathrm{a}}$ & $90.7^{\mathrm{a}}$ & $87.9^{\mathrm{a}}$ & $5.56^{\mathrm{a}}$ & $10.00^{\mathrm{a}}$ & $5.91^{\mathrm{a}}$ \\
\hline
\end{tabular}

RE - radicle emergence test; FCSG - first count in standard germination test; SG - standard germination; CT - cold test; AA - accelerated ageing test; RLSG - root length in SG; RLCT - root length in CT; RLAA root length in AA; Different letters in each column indicate significant differences between average estimates tested by Analysis of variance of arcsin transformed percentages.

Natural seed ageing in two different conditions (storage room and cold chamber) had a significant influence on all observed seed quality parameters (Table 3 ). The percentage of physiological germination significantly differed among the two observed storage conditions. Radicle emergence test estimates of seeds stored in a cold chamber were twice as high (40.8\%), as those from the seed seeds stored in storage room conditions (17.9\%). Poorer storage conditions resulted in slower germination that responded to a reduced number of normal seedlings in the first count in the germination test. The average estimate of SG of seed stored in a cold chamber was $96.5 \%$ while naturally aged seed stored at $18{ }^{\circ} \mathrm{C}$, showed a reduction of SG for almost $6 \%$ (Table 3). Root length in all three tests (SG, CT and AA) decreased after seed storage at $18{ }^{\circ} \mathrm{C}$. Natural ageing mostly affected root length in the AA test, where the average estimate of all inbred lines stored in a cold chamber was $5.91 \mathrm{~cm}$, which was twice as the one for the seed stored at $18^{\circ} \mathrm{C}(2.97 \mathrm{~cm})$. 
Higher differences in seed quality among maize inbred lines were established by vigour tests compared to the standard germination test (Table 3).

Estimates of SG of seed stored in a cold chamber ranged from $90 \%$ (ZPL 5) to $100 \%$ (five inbred lines). On the other hand, different responses to seed storage among maize inbred lines were noticed, so the germination in optimal conditions ranged from $60 \%$ to $99 \%$ (Figure 1). Moreover, FCSG identified even higher differences between genotypes (Table 4).

Application of CT provided even better screening of maize inbred lines seed vigour and testing their tolerance to low temperatures during early growth. Average estimates (90.7 and $82.1 \%$ for seed storage at $18{ }^{\circ} \mathrm{C}$ and in cold chamber respectively) indicate that $\mathrm{ZP}$ maize inbred lines possess a very good response to extremely stressful conditions $\left(7.5^{\circ} \mathrm{C}, 10\right.$ days). This test identified that natural ageing affected tolerance to low temperature inducing higher susceptibility at lines ZPL 3 and ZPL 6 (Figure 1). On the other hand, the highest CT estimates were noticed for ZPL 4 in both storage conditions.

CC

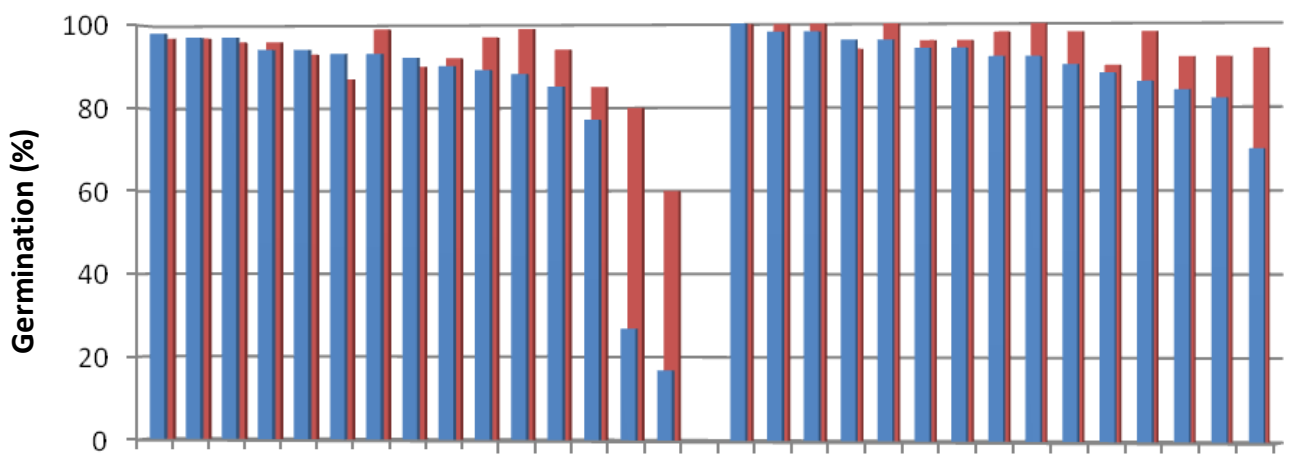

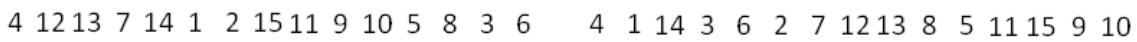

Inbred line

Figure 1. Standard germination (SG) and cold test (CT) results for inbred lines seed, stored in conditions of storage room and cold chamber. Inbred lines are sorted according to CT estimates.

Grafikon 1. Standardna klijavost (SG) i hladni test (CT) samooplodnih linija čuvanih u uslovima skladišta $i$ hladne komore. Samooplodne linije su raspoređene prema vrednostima u hladnom testu.

AA test provided more pronounced differentiation between inbred lines than CT. Estimates ranged from $17 \%$ (ZPL 10) to $99 \%$ (ZPL 13 ) in seed stored in a cold chamber. Seed of the line ZPL 10 , stored at $18^{\circ} \mathrm{C}$ (storage room), completely lost the germination ability after application of high temperatures and $\mathrm{RH}$, while ZPL 4 retained high seed vigour (96\%). 
Table 4. Average estimates of analyzed maize seed quality parameters and rank of inbred lines. The rank of the inbred line within each test is shown beside the mean value.

Tabela 4. Prosečne vrednosti ispitivanih parametara kvaliteta i rang samooplodnih linija. Rang samooplodne linije unutar svakog testa je data pored proseka.

\begin{tabular}{|c|c|c|c|c|c|c|c|c|c|}
\hline \multirow{2}{*}{$\begin{array}{l}\text { Inbred } \\
\text { line }\end{array}$} & \multicolumn{9}{|c|}{ Germination (\%) } \\
\hline & RE & Rank & FCSG & Rank & SG & Rank & CT & Rank & AA \\
\hline 4 & $30.0^{\mathrm{bcd}}$ & 6 & $95.5^{\mathrm{ab}}$ & 4 & $98.5^{\mathrm{a}}$ & 1 & $99.0^{\mathrm{a}}$ & 1 & $96.5^{\mathrm{a}}$ \\
\hline 13 & $37.0^{\mathrm{bc}}$ & 4 & $95.0^{\mathrm{ab}}$ & 5 & $98.0^{\mathrm{a}}$ & 2 & $94.5^{\text {bcde }}$ & 5 & $80.0^{\text {bcde }}$ \\
\hline 2 & $26.5^{\text {cde }}$ & 8 & $96.5^{\mathrm{a}}$ & 1 & $97.5^{\mathrm{ab}}$ & 5 & $93.5^{\text {bcde }}$ & 6 & $91.5^{\mathrm{ab}}$ \\
\hline 12 & $23.5^{\mathrm{def}}$ & 9 & $95.5^{\mathrm{ab}}$ & 3 & $97.5^{\mathrm{ab}}$ & 3 & $94.5^{\text {bcde }}$ & 7 & $85.5^{b c d}$ \\
\hline 1 & $20.5^{\mathrm{efg}}$ & 11 & $86.0^{\mathrm{bcd}}$ & 10 & $93.5^{\mathrm{abcde}}$ & 8 & $95.5^{\mathrm{abc}}$ & 3 & $93.5^{\mathrm{ab}}$ \\
\hline 14 & $12.50^{\mathrm{gh}}$ & 13 & $89.5^{\mathrm{bcd}}$ & 9 & $96.5^{\mathrm{ab}}$ & 4 & $96.0^{\mathrm{ab}}$ & 2 & $91.0^{\mathrm{abc}}$ \\
\hline 11 & $61.0^{\mathrm{a}}$ & 1 & $93.0^{\mathrm{abc}}$ & 6 & $95.0^{\mathrm{abcde}}$ & 9 & $88.0^{\text {cdef }}$ & 8 & $84.5^{\text {bcde }}$ \\
\hline 8 & $59.0^{\mathrm{a}}$ & 2 & $91.0^{\mathrm{abcd}}$ & 7 & $91.5^{\text {bcdef }}$ & 11 & $83.5^{\mathrm{f}}$ & 12 & $76.5^{\mathrm{def}}$ \\
\hline 3 & $33.5^{\mathrm{bcd}}$ & 5 & $79.5^{\mathrm{de}}$ & 14 & $87.0^{\mathrm{ef}}$ & 14 & $61.5^{\text {gh }}$ & 14 & $69.5^{\mathrm{fg}}$ \\
\hline 9 & $31.0^{\mathrm{bcd}}$ & 7 & $90.5^{\mathrm{abcd}}$ & 8 & $94.5^{\text {abcdef }}$ & 10 & $85.5^{\mathrm{ef}}$ & 11 & $54.5^{\mathrm{h}}$ \\
\hline 7 & $21.5^{\mathrm{efg}}$ & 10 & $85.0^{\mathrm{de}}$ & 13 & $96.0^{\mathrm{abcd}}$ & 7 & $94.0^{\mathrm{bcd}}$ & 4 & $80.0^{\text {cde }}$ \\
\hline 10 & $9.0^{\mathrm{h}}$ & 15 & $95.5^{\mathrm{ab}}$ & 2 & $96.5^{\mathrm{abc}}$ & 6 & $79.0^{\mathrm{fg}}$ & 13 & $8.5^{\mathrm{i}}$ \\
\hline 5 & $16.5^{\mathrm{fgh}}$ & 12 & $87.0^{\mathrm{cd}}$ & 12 & $92.0^{\text {cdef }}$ & 12 & $86.5^{\text {ef }}$ & 10 & $87.5^{\text {bcde }}$ \\
\hline 6 & $43.5^{\mathrm{b}}$ & 3 & $66.0^{\mathrm{e}}$ & 15 & $80.0^{\mathrm{f}}$ & 15 & $56.5^{\mathrm{h}}$ & 15 & $57.0^{\mathrm{gh}}$ \\
\hline 15 & $15.5^{\mathrm{h}}$ & 14 & $87.5^{\mathrm{cd}}$ & 11 & $91.0^{\mathrm{def}}$ & 13 & $88.0^{\text {def }}$ & 9 & $76.0^{\text {ef }}$ \\
\hline \multirow{2}{*}{$\begin{array}{l}\text { Inbred } \\
\text { line }\end{array}$} & \multicolumn{9}{|c|}{ Root lenght (cm) } \\
\hline & Rank & RLSG & Rank & RLCT & Rank & RLAA & Rank & & Pedigree \\
\hline 4 & 1 & $6.00^{\mathrm{a}}$ & 2 & $10.60^{\mathrm{abc}}$ & 5 & $6.15^{\mathrm{ab}}$ & 2 & & IDxUN \\
\hline 13 & 7 & $6.05^{\mathrm{a}}$ & 1 & $10.30^{\mathrm{abcd}}$ & 6 & $6.35^{\mathrm{a}}$ & 1 & & BSSS \\
\hline 2 & 3 & $5.70^{\mathrm{ab}}$ & 3 & $11.10^{\mathrm{a}}$ & 1 & $5.15^{\mathrm{cd}}$ & 6 & & ID \\
\hline 12 & 5 & $5.70^{\mathrm{ab}}$ & 4 & $10.75^{\mathrm{ab}}$ & 3 & $5.35^{\mathrm{bcd}}$ & 5 & & BSSS \\
\hline 1 & 2 & $5.30^{\mathrm{bcd}}$ & 9 & $11.00^{\mathrm{a}}$ & 2 & $5.85^{\mathrm{abc}}$ & 3 & & ID \\
\hline 14 & 4 & $4.75^{\mathrm{e}}$ & 13 & $10.70^{\mathrm{ab}}$ & 4 & $4.75^{\mathrm{d}}$ & 9 & & BSSS \\
\hline 11 & 8 & $5.50^{\mathrm{bc}}$ & 8 & $8.15^{\mathrm{fg}}$ & 14 & $5.05^{\mathrm{cd}}$ & 7 & & BSSSxID \\
\hline 8 & 10 & $5.50^{\mathrm{b}}$ & 7 & $9.15^{\text {cdef }}$ & 11 & $4.90^{\mathrm{cd}}$ & 8 & & BSSSxID \\
\hline 3 & 12 & $5.50^{\mathrm{b}}$ & 6 & $9.35^{\text {abcdef }}$ & 8 & $5.70^{\mathrm{abcd}}$ & 4 & & ancaster \\
\hline 9 & 14 & $5.05^{\mathrm{de}}$ & 11 & $10.00^{\text {abcde }}$ & 7 & $2.45^{\mathrm{f}}$ & 14 & & SSSSxUN \\
\hline 7 & 9 & $3.90^{\mathrm{f}}$ & 15 & $7.15^{\mathrm{g}}$ & 15 & $3.80^{\mathrm{e}}$ & 10 & & ancaster \\
\hline 10 & 15 & $5.10^{\text {cde }}$ & 10 & $9.00^{\mathrm{def}}$ & 12 & $1.00^{\mathrm{g}}$ & 15 & & 3SSSxEX \\
\hline 5 & 6 & $5.05^{\mathrm{de}}$ & 12 & $8.50^{\text {efg }}$ & 13 & $3.30^{\mathrm{ef}}$ & 12 & & ancaster \\
\hline 6 & 13 & $5.55^{\mathrm{b}}$ & 5 & $8.60^{\text {cdef }}$ & 10 & $3.15^{\mathrm{ef}}$ & 13 & & ancaster \\
\hline 15 & 11 & $4.21^{\mathrm{f}}$ & 14 & $9.50^{\text {bcdef }}$ & 9 & $3.65^{\mathrm{e}}$ & 11 & & BSSS \\
\hline
\end{tabular}

$\mathrm{RE}$ - radicle emergence test; FCSG - first count in standard germination test; SG - standard germination; CT - cold test; AA - accelerated ageing test; RLSG - root length in SG; RLCT - root length in CT; RLAA root length in AA; ID - Iowa Dent; UN - unrelated germplasm; EX - exotic germplasm.

In each column estimates with the same letter in common are not significantly different as indicated by $\operatorname{LSD}(\mathrm{P} \leq 0.05)$ test. 
Genotype had a significant influence on investigated seed quality parameters, which were related to pedigree of inbred lines (Table 4). According to average estimates for both storage conditions, inbred lines were ranked for each seed quality parameter. Overall rank was used to sort inbred lines in descending order (from the most to the least vigorous). Inbred line ZPL 4, selected from Iowa Dent x unrelated germplasm had the best seed quality in laboratory tests. Inbred lines with Lancaster background showed lower seed quality (placed at the bottom of Table 4) compared to inbred lines with BSSS and Iowa Dent background.

Table 5. Spearman rank coefficient between applied laboratory tests

Tabela 5. Spirmanov koeficijent ranga izmedu primenjenih laboratorijskih testova

\begin{tabular}{|c|c|c|c|c|c|c|c|c|}
\hline & & FCSG & SG & CT & AA & RLSG & RLCT & RLAA \\
\hline SR & $\mathrm{RE}$ & 0.15 & 0.06 & 0.17 & 0.30 & $0.52^{\star}$ & 0.07 & $0.59^{\star}$ \\
\hline $\mathrm{CC}$ & & $0.58^{*}$ & 0.24 & 0.02 & 0.15 & $0.64^{* *}$ & -0.09 & 0.42 \\
\hline SR & FCSG & & $0.88^{\star *}$ & 0.48 & 0.23 & 0.47 & 0.47 & 0.10 \\
\hline $\mathrm{CC}$ & & & $0.58^{\star}$ & 0.22 & 0.43 & $0.71^{\star *}$ & 0.36 & $0.74^{* *}$ \\
\hline SR & SG & & & $0.54^{*}$ & 0.19 & 0.33 & 0.33 & -0.06 \\
\hline $\mathrm{CC}$ & & & & $0.70^{* *}$ & $0.66^{* *}$ & 0.29 & 0.43 & $0.71^{* *}$ \\
\hline SR & CT & & & & $0.66^{* *}$ & 0.23 & $0.53^{\star}$ & 0.39 \\
\hline CC & & & & & $0.53^{*}$ & 0.00 & 0.47 & $0.58^{*}$ \\
\hline SR & AA & & & & & 0.43 & $0.53^{*}$ & 0.48 \\
\hline $\mathrm{CC}$ & & & & & & 0.20 & 0.47 & $0.64^{* *}$ \\
\hline SR & RLSG & & & & & & $0.58^{\star}$ & $0.57^{\star}$ \\
\hline $\mathrm{CC}$ & & & & & & & 0.34 & $0.57^{\star}$ \\
\hline SR & RLCT & & & & & & & 0.50 \\
\hline CC & & & & & & & & $0.62^{*}$ \\
\hline
\end{tabular}

RE - radicle emergence test; FCSG - first count in standard germination test; SG - standard germination; CT - cold test; AA - accelerated ageing test; RLSG - root length in SG; RLCT - root length in CT; RLAA root length in AA; SR - storage room; CC - cold chamber; ${ }^{*},{ }^{* *}$ - significant at $0.05,0.01$ probability level.

Correlation coefficient ranks between all observed seed quality parameters were determined for each storage condition separately (Table 5). It was noticed that RE test results were not correlated to the other vigour test results (CT and AA). For example, ZPL 6 ranked $3^{\text {rd }}$ in RE, and it was ranked $15^{\text {th }}$ in SG and other vigour tests (Table 4 ). Vice versa, the inbred with the best seed quality ZPL 4 ranked $6^{\text {th }}$ in RE. The only positive and significant correlation was found between RE and RLSG.

The correlation between FCSG and SG was in both cases significant and positive ( 0.88 and 0.58). A significant correlation between SG and CT was observed for both seed storage conditions, while between SG and AA only for the seed stored in a cold chamber. Corre- lations between CT and AA were significant (0.66 and 0.53).

Root length (AA) was in accordance with the most number of other tests (Table 5). RLSG was not in agreement with the percentage of normal seedlings in CT and AA, but it correlated to RL in CT and AA.

\section{Discussion}

Standard germination did not show variations between genotypes whose seeds were stored in controlled conditions at $5{ }^{\circ} \mathrm{C}$. Storing seeds for four years at $18{ }^{\circ} \mathrm{C}$ reduced the germination of certain genotypes. Some inbred lines retained high SG, so larger variability according to this seed quality parameter was noticed. Obtained results are in accordance with 
TeKrony et al. (2001) and confirm that the seed of maize inbred lines could maintain seed quality as good as the seed of hybrids of the same initial quality. Higher differences in seed quality among maize inbred lines were achieved by vigour tests compared to the standard germination test. Equally, Liu et al. (2019) in testing two inbred lines showed large differences in seed vigour after artificial ageing treatment, while they had similar performances in terms of most agronomic traits.

SG estimates were in good agreement with other vigour tests (CT and AA) because the tested material is of wide genetic background. After prolonged storage in less favourable conditions, this correlation was to some extent lower, which was expected due to the fact that seed vigour is more affected by seed storage than SG.

RLSG was not in correlation with estimates of vigour tests except RE. RLAA and RLCT were in better concurrence with the ranking of genotypes in other tests. Although a number of authors (Mondo et al., 2013; Alvarenga et al., 2012) emphasized the importance of estimation of seedling size in vigour assessment, obtained results indicate that this parameter had limited application in this research of seed quality evaluation of maize inbred lines of wide genetic background. Examining the efficiency of classification of seed lots in two maize hybrids Pinto et al. (2015) found that RL was more suitable for one, while coleoptiles length for the other hybrid.

Seed vigour tests enabled better classification of maize inbred lines in terms of seed quality than standard germination tests. A standard germination test is designed for the purposes of differentiation among seed lots according to their germination potential, which was observed by Petrović et al. (2019). Application of CT provided reliable screening of maize inbred lines tolerance to chilling stress during early growth. Increasing the chilling tolerance of maize genotypes as a result of breeding activity and natural selection requires more stressful conditions in CT in order to achieve adequate classification. Lovato et al. (2005) examined the effect of three different temperatures $(5,7.5$ and $10^{\circ} \mathrm{C}$ ) in $\mathrm{CT}$ on maize seed germination. Their results showed that $10{ }^{\circ} \mathrm{C}$ in $\mathrm{CT}$ is suitable for the discrimination of maize seed lots, but lower temperatures $\left(5\right.$ and $7.5^{\circ} \mathrm{C}$ ) are better in testing highly tolerant maize seed lots.

In this research extremely stressful CT was applied, with temperatures of $7.5^{\circ} \mathrm{C}$ in a cold period lasting 10 days. The results showed very good tolerance of $\mathrm{ZP}$ inbred lines to the applied test conditions, except for inbred lines ZPL 3 and ZPL 6, whose sensitivity was manifested after seed storage at $18{ }^{\circ} \mathrm{C}$ during four years. These inbred lines originate from the Lancaster population, which is generally characterized by poor tolerance to low temperatures during emergence and good tolerance to high temperatures during fertilization and grain filling. The other two inbred lines (ZPL 5 and ZPL 7), which also have a Lancaster background showed no sensitivity to cold stress. This is explained by the contribution of other parents' germplasm who participated in the selection process of those inbred lines.

Comparison between CT and AA test results showed that inbred lines with poor tolerance to cold stress were also susceptible to high temperature and high RH stress. This is consistent with the research of Timperio et al. (2008) which stated that the physiological adaptation of maize, which involves the activation of the antioxidant system, is equal in both temperature stresses. In the study of Xiaoyang et al. (2021), F2:3 and RILs derived from two maize lines were subjected to an artificial ageing treatment to map QTL for traits related to seed storability. They concluded that four SSR markers screened in this research could be used for the selection of maize germplasm with a high degree of seed storability. The cold test was in good agreement with the results of field experiments when lower temperatures prevailed in spring (Milivojevic et al., 2017).

Although AA and CT are widely used, they are still not standardized for testing maize seed vigour. Recent studies have contributed to the introduction of the radicle emergence test in the ISTA Rules. The application of the RE test as an integral part of the standard germination test can be extremely practical for simultane- 
ous evaluation of seed germination and vigour, thus saving time and seeds. Contrary to the findings Khajeh-Hosseini et al. (2009) and Matthews et al. (2010, 2011), the RE test in this study did not show good agreement with other vigour tests. Further investigation will involve the field emergence of inbred lines.

\section{Conclusions}

Obtained results indicate that the application of either CT or AA test is reliable for screening seed vigour of maize inbred lines. Testing newly produced seed together with aged seed is recommended for more precise identification of inbred lines in terms of seed vigour. Information of inbred lines pedigree is useful and can be used as an indicator of seed vigour.

\section{Acknowledgments}

This research was supported by the Ministry of Education, Science and Technological Development, Republic of Serbia, under Grant no. 451-03-68/2020-14/200040.

\section{References}

Alvarenga RO, Marcos Filho J, Gomes Junior FG (2012): Avaliação do vigor de sementes de milho super doce por meio da análise computadorizada de imagens de plântulas. [Evaluation of supersweet corn seed vigor using an automated computer imaging system]. Rev. Bras. Semen., 34: 488-494.

Andrade GC, Medeiros Coelho CM, Uarrota VG (2020): Modelling the vigour of maize seeds submitted to artificial accelerated ageing based on ATR-FTIR data and chemometric tools (PCA, HCA and PLS-DA). Heliyon, 6(2): 03477.

Bonelli LE, Monzonb JP, Cerrudoa A, Rizzalli RH, Andradea FH (2016): Maize grain yield components and source-sink relationship as affected by the delay in sowing date. Field Crops Research, 198: 215-225.

Darkó É, Fodor J, Dulai S, Ambrus H, Szenzenstein A, Kira Z, Barnaba B (2011): Improved cold and drought tolerance of doubled haploid maize plants selected for resistance to prooxidant tert-butyl hydroperoxide. J. Agron. Crop Sci., 197: 454-465.

Delouche JC, Baskin CC (1973): Accelerating aging techniques for predicting the relative storability of seed lots. Seed Sci. Technol, 1: 427-452.

Frascaroli E, Landi P (2013): Divergent selection in a maize population for germination at low temperature in controlled environment: Study of the direct response, of the trait inheritance and of correlated responses in the field. Theor. Appl. Genet., 126: 733-746.

Goggi AS, Pollak L, Golden J, DeVries M, McAndrews G, Montgomery K (2007): Impact of early seed quality selection on maize inbreds and hybrids. Maydica, 52: 223-233. Grzybowski M, Adamczyk J, Jończyk M, Sobkowiak A, Szczepanik J, Frankiewicz K, Fronk J, Sowiński P (2019): Increased photosensitivity at early growth as a possible mechanism of maize adaptation to cold springs. Journal of Experimental Botany, 70 (10): 2887-2904.

Hampton JG, TeKrony DM (1995): Handbook of Vigour Test Methods, $3^{\text {rd }}$ edition. Zurich, Switzerland, ISTA. pp. 117.

ISTA (2015): International Rules for Seed Testing. International Seed Testing Association, Bassersdorf, Switzerland.

Khajeh-Hosseini M, Lomholt A, Matthews S (2009): Mean germination time in the laboratory estimates the relative vigour and field emergence of commercial seed lots of maize (Zea mays L.). Seed Sci. Technol., 37: 446-456.

Li H, Yue H, Xie J, Bu J, Li L, Xin X, Zhao Y, Zhang H, Yang L, Wang J, Jiang X (2021): Transcriptomic profiling of the high-vigour maize (Zea mays L.) hybrid variety response to cold and drought stresses during seed germination. Scientific Reports, 11: 19345.

Liu Y, Zhang H, Li X, Wang F, Lyle D, Sun L, Wang G, Wang J, Li L, Gu R (2019): Quantitative trait locus mapping for seed artificial aging traits using an $\mathrm{F}_{2: 3}$ population and a recombinant inbred line population crossed from two highly related maize inbreds. Plant Breed., 138: 29-37. 
Lovato A, Noli E, Lovato AFS (2005): The relationship between three cold test temperatures, accelerated ageing test and field emergence of maize seed. Seed Sci. Technol., 33: 249-253.

Matthews S, Beltrami E, El-Khadem R, Khajeh-Hosseini M, Nasehzadeh M, Urso G (2011): Evidence that time for repair during early germination leads to vigour differences in maize. Seed Sci. Technol., 39: 501-509.

Matthews S, El-Khadem R, Casarini E, Khajeh-Hosseini M, Nasehzadeh M, Wagner MH (2010): Rate of physiological germination compared with the cold test and accelerated ageing as a repeatable vigour test for maize. Seed Sci. Technol., 34: 379-389.

Medeiros AD, Pereira MD, Freire Silva ÍF, Capobiango NP, Pereira Flores ME (2019): Vigor of maize seeds determined by a free image analysis system. Revista Ciencia Agronomica, 50(4): 616-624.

Milivojević M, Nikolić A, Marković K, Filipović M, Vančetović J, Petrović T, Srdić J (2017): Relationship between genetic diversity and cold-tolerance of maize inbred lines. Genetika, 49(2): 635-646.

Mondo VHV, Cicero SM, Dourado-Neto D, Pupim TL, Dias MAN (2013): Seed vigor and initial growth of corn crop. J. Seed Sci., 35: 64-69.

Nerling D, Medeiros Coelho CM, Brümmer A (2018): Biochemical profiling and its role in physiological quality of maize seeds. Journal of Seed Science, 40 (1): 007-015.

Petrović T, Radosavljević N, Babić M, Milivojević M, Vukadinović R, Branković-Radojčić D (2019): Standard germination and seedling emergence of maize inbred lines in different temperature conditions. Selekcija i semenarstvo, 25(1): 9-14.

Pinto CAG, Carvalho MLM, Andrade DB, Leite ER, Chalfoun I (2015): Análise de imagens na avaliação do potencial fisiológico de sementes de milho. [Image analysis in the evaluation of the physiological potential of maize seeds.]. Rev. Ciência. Agron., 46: 319-328.
Revilla P, Butrón A, Cartea ME, Malva RA, Ordás A (2005): Breeding for cold tolerance. In: M. Ashraf and P.J.C. Harris, editors, Abiotic stresses. Plant resistance through breeding and molecular approaches. The Haworth Press, Inc., New York.

Revilla P, Rodríguez VM, Ordas A (2014): Cold tolerance in two large maize inbred panels adapted to European climates. Crop Sciences, 54: 1981-1991.

Sabry GE (2018): The Importance of Using High Quality Seeds in Agriculture Systems. Agri Res \& Tech, 15(4): 555961.

Strigens A, Freitag NM, Gilbert X, Grieder C, Riedelsheimer C, Schrag TA, Messmer R, Melchinger AE (2013): Association mapping for chilling tolerance in elite flint and dent maize inbred lines evaluated in growth chamber and field experiments. Plant Cell Environ., 36: 1871-1887.

Strigens A, Grieder C, Haussmann BIG, Melchinger AE (2012): Genetic variation among inbred lines and testcrosses of maize for early growth parameters and their relationship to final dry matter yield. Crop Sci., 52: 1084-1092.

TeKrony DM, Egli DB, Rucker M (2001): Survival characteristics of inbred corn seed during storage. Seed Technol., 23: 197-205.

Timperio AM, Egidi MG, Zolla L (2008): Proteomics applied on plant abiotic stresses: Role of heat shock proteins (HSP). J. Proteomics, 71: 391-411.

Tsimba R, Edmeades GO, Millner JP, Kemp PD (2013): The effect of planting date on maize: Phenology, thermal time durations and growth rates in a cool temperate climate. Field Crops Research, 150: 145-155.

Woltz JM, TeKrony DM (2001): Accelerated ageing test for corn seed. Seed Technol., 23: 21-34

Xiaoyang G, Sun X, Liu S, Gong C, Feng C, Han X, Lv T, Zhou Y, Wang Z, Di H (2021): Screening and application of SSR markers related to seed storability traits in maize (Zea mays L.). Genet Resour Crop Evol., 68: 2521-2535. 


\title{
PRIMENA TESTOVA STANDARDNE KLIJAVOSTI I VIGOR TESTOVA U PROCENI KVALITETA SEMENA SAMOOPLODNIH LINIJA KUKURUZA
}

\author{
Marija Milivojević, Jelena Srdić, Milomir Filipović, Tanja Petrović, Dragana \\ Branković Radojčić, Ksenija Marković, Jan Boćanski
}

\begin{abstract}
Izvod
Semenskim kompanijama su od izuzetne važnosti informacije o adaptibilnosti samooplodnih linija kukuruza (Zea mays L.) različitim uslovima u polju i dugovečnosti semena. Cilj ovog rada bio je da se izvrši procena vigor testova za otkrivanje razlika između prirodno ostarelog semena u različitim uslovima čuvanja i da se proceni odnos između parametara kvaliteta semena i podataka o pedigreu samooplodnih linija kukuruza. Seme 15 samooplodnih linija kukuruza selekcionisanih u "Institutu za kukuruz" - Zemun Polje, koje pripadaju različitim heterotičnim grupama, proizvedeno je 2011. godine. Kvalitet semena je ocenjivan 2015. godine primenom standardnog testa za klijavost, testa za pojavu primarnog korena, ubrzanim starenjem i hladnim testom. U svim primenjenim ispitivanjima merena je dužina korena klijanaca starih 4 dana. Analiza varijanse je pokazala da genotip i uslovi čuvanja semena imaju značajan uticaj na sve parametre kvaliteta semena. Samooplodne linije kukuruza su se značajno razlikovale u pogledu vigora semena na osnovu tri primenjena testa, a naročito testa ubrzanog starenja. Rezultati hladnog testa su pokazali visoku tolerantnost ispitivanih genotipova na niske temperature prilikom nicanja, osim dve samooplodne linije Lancaster porekla. Korelacija između hladnog testa i testa ubrzanog starenja bila je značajna, dok je test pojave primarnog korena imao slabu korelaciju sa njima. Dobijeni rezultati ukazuju da je primena hladnog testa i testa ubrzanog starenja pouzdana za skrining vigora semena samooplodnih linija kukuruza.
\end{abstract}

Ključne reči: klijavost, kukuruz, kvalitet semena, samooplodne linije, vigor

Primljen: 20.11.2021. Prihvaćen: 01.12.2021. 